\title{
Investigating the distribution of magmatism at the onset of Gondwana breakup with novel strapdown gravity and aeromagnetic data
}

Tom A. Jordan ${ }^{* 1}$ and David Becker ${ }^{2}$

1* British Antarctic Survey, High Cross, Madingley Road, Cambridge CB3 OET (tomj@bas.ac.uk).

${ }^{2}$ Chair of Physical and Satellite Geodesy, Technische Universität Darmstadt, Franziska-Braun-Str. 7, 64287 Darmstadt, Germany.

Cite: Jordan, Tom A.; Becker, David. 2018 Investigating the distribution of magmatism at the onset of Gondwana breakup with novel strapdown gravity and aeromagnetic data. Physics of the Earth and Planetary Interiors, 282. 77-88. https://doi.org/10.1016/i.pepi.2018.07.007

\section{Abstract:}

Massive volumes of mafic magmatism forming the Karoo-Ferrar Large Igneous Province (LIP) in Southern Africa and Antarctica preceded Jurassic breakup of the Gondwana Supercontinent. This widespread LIP magmatism is attributed to a major mantle plume, or plumes, impacting an area thousands of kilometres across. Magmas in lava flows and shallow sills, which flowed laterally hundreds to thousands of kilometres, form most of the exposed LIP. Hence, the distribution of shallow level mafic rocks may not reflect the location of mantle melting. In contrast, large deepseated mafic intrusions such as gabbros likely more directly overlie areas of mantle melting. Antarctic exposures of such intrusions are limited to the Dufek Intrusion and outcrops $>1000 \mathrm{~km}$ to the north, hence the true pattern of mantle melting is poorly constrained. Regional aeromagnetic and aerogravity data suggest other Jurassic mafic intrusions are present, but detailed analysis of these bodies is lacking. To define more precisely the distribution of mafic intrusions we use data from the first stand-alone strapdown gravity survey in Antarctica. This innovative technique allows collection of aerogravity data during draped flight, resolving anomalies with a wavelength of $\sim 6 \mathrm{~km}$ and a root-mean-square error of $1.8 \mathrm{mGal}$. Combining this new gravity data with coincident 
aeromagnetic data we investigate a $\sim 50 \mathrm{mGal}$ gravity and associated $>1000 \mathrm{nT}$ magnetic high in Coats Land, East Antarctica. Our interpretation is that the so called 'Halley High' reflects a large gabbroic body $\sim 80 \mathrm{~km}$ long, $30 \mathrm{~km}$ wide and $\sim 6 \mathrm{~km}$ thick, equivalent to the inferred total size to the better known Stillwater layered mafic intrusion in the US. Our interpretation of a large mafic intrusion supports the suggestion from reconnaissance aeromagnetic data that this and other similar anomalies are Jurassic mafic intrusions. These large mafic intrusions, and hence underlying mantle melting, appear restricted to a linear band parallel to the continental margin. This structured pattern of mantle melting is consistent with shallow mantle convection and lithospheric extension playing a significant role in the later stages of the Karoo-Ferrar magmatism. An apparent $650 \mathrm{~km}$ gap in mafic intrusions adjacent to the continental Weddell Sea Rift System suggests different mantle processes were occurring here. Future joint magnetic and strapdown gravity surveying presents a key opportunity to fully constrain the location and extent of mantle melting during Gondwana breakup.

Key words: Mafic intrusion; Antarctica; Jurassic; mantle plume; volcanic rifted margin; Karoo

\section{Introduction}

Breakup of Gondwana was associated with massive volumes of magmatism. The exposed magmas are dominated by shallow level Karoo Continental Flood Basalts (CFB) in South Africa and Dronning Maud Land, and the Ferrar sill complex elsewhere in Antarctica (Elliot and Fleming, 2000). Given their approximate coincident age, these two provinces are often amalgamated into the KarooFerrar Large Igneous Province (LIP), which extends from southern Africa around the Dronning Maud Land, Coats Land and Transantarctic Mountain margins of East Antarctica, a distance of $>3000 \mathrm{~km}$ (Fig. 1) (Elliot, 1992; Elliot and Fleming, 2000; Ferraccioli et al., 2005; Jourdan et al., 2005; Riley et al., 2005). This major magmatic event is widely attributed to the impact of a significant mantle plume at the base of the Gondwanan lithosphere, which was associated with magmatism and subsequent continental rifting (Storey, 1995; Storey et al., 2013; White and McKenzie, 1989). The extent of the 
mantle plume, super plume, or multiple plume heads is difficult to constrain given the proposed $100 \mathrm{~s}$ to $1000 \mathrm{~s} \mathrm{~km}$ of lateral transport of surficial flood basalts and sills (Elliot et al., 1999; Leat, 2008; Luttinen et al., 2010). Deep-seated large mafic intrusions, which reflect igneous centres, may be better indicators of the areas of mantle melting, as suggested in the North Atlantic LIP (Geoffroy et al., 2007). Unfortunately, deeper level mafic intrusions associated with the Karoo-Ferrar LIP in Antarctica are only exposed in two areas (Fig. 1) (Semenov et al., 2014). Firstly Vestfjella in Dronning Maud land where two separate layered Gabbro intrusions up to $25 \mathrm{~km}^{2}$ and $3 \mathrm{~km}$ thick are seen cross cutting the CFB sequences (Vuori and Luttinen, 2003).Secondly the Dufek Intrusion $1000 \mathrm{~km}$ further south, suggested from geological observations to cover an area of $24,000-34,000 \mathrm{~km}^{2}$ with an estimated thickness of 8-9km (Ford and Himmelberg, 1991), although aeromagnetic data suggests an area of closer to $6600 \mathrm{~km}^{2}$ (Ferris et al., 1998). Gabbroic intrusions such as the Mount Ayliff/Insizwa complex and the New Amalfi intrusion are also seen in Southern Africa (Lightfoot and Naldrett, 1983) where geological and geophysical considerations suggest such bodies are sill-like structures $\sim 1 \mathrm{~km}$ thick, with an original area of $\sim 2000 \mathrm{~km}^{2}$ (Lightfoot and Naldrett, 1983; Sander and Cawthorn, 1996).

The sub-ice extent of individual Antarctic intrusions has been investigated using aerogeophysical data, although precise determination of intrusion size has been controversial (Behrendt et al., 1981; Ferris et al., 1998; Semenov et al., 2014). A number of additional magnetic anomalies of high to moderate amplitudes associated with magmatism during Gondwana break up are inferred within the continental crust from regional aeromagnetic compilations (Corner, 1994; Golynsky and Aleshkova, 1997; Leitchenkov et al., 1996), regional aerogravity data (Aleshkova et al., 1997) and ground based surveys (Ruotoistenmäki and Lehtimäki, 1997). However, the details of these features have remained scarce due to the reconnaissance nature of the geophysical data coverage. Here we use new $5 \mathrm{~km}$ line spacing aeromagnetic data and innovative new strapdown aerogravity data collected over the Brunt Ice Shelf in 2017, to investigate in detail the structure and origin of one of these key anomalies. Using a range of digital enhancements, depth to source 
calculation and modelling we propose that a significant, likely Jurassic, mafic body is present beneath the northern margin of the Brunt Ice Shelf. Confirmation of this anomaly as a large mafic intrusion supports previous interpretations of numerous mafic bodies lying along the Antarctic rifted margin e.g. (Golynsky and Aleshkova, 1997), and hence the concept of regionally extensive mantle melting feeding the Karoo-Ferrar LIP. The implications of this interpretation for the distribution, timing, mechanism and possible analogues for magma generation at the onset of Gondwana breakup are discussed.

\subsection{Geographical and geological setting}

The study area lies beneath the Brunt Ice Shelf, $\sim 80 \mathrm{~km}$ south from the continental shelf break and the deep ocean floor of the Weddell Sea (Fig. 1a). West of the study area is the Weddell Sea Rift System, a Jurassic continental rift overlain by a broad sediment-filled marine basin (Jordan et al., 2017; Leitchenkov and Kudryavtzev, 1997; Studinger and Miller, 1999). To the south and east of the study area is the East Antarctic continent, which is typically blanketed by the 2-4 km thick East Antarctic Ice Sheet, although sparse outcrops along the coast and in some inland mountain chains allow assessment of the underlying geology (Fig. 1a). The overarching geological structure of this part of East Antarctica is an ancient continental collision zone. The oldest rocks in Dronning Maud Land are $\sim 3 G a$ and form a cratonic core around which a series of continental arcs and ocean arc terranes developed. These arcs were accreted to the cratonic core prior to and during the $\sim 1 \mathrm{Ga}$ continental Grenville Orogen (Jacobs et al., 2008; Marschall et al., 2013). The amalgamation of West Gondwana (Southern Africa and South America) and East Gondwana (India, East Antarctica and Australia) during the subsequent $\sim 500 \mathrm{Ma}$ Pan-African event led to additional deformation and metamorphism, seen in both Dronning Maud Land and the Shackleton Range. The Coats Land region may have acted as an independent rigid cratonic fragment during this event (Jacobs and Thomas, 2004; Studinger and Miller, 1999). 
The wide spread Karoo-Ferrar magmas (Fig. 1b) were emplaced in a short time interval around 183 Ma (Burgess et al., 2015; Svensen et al., 2012). Dating evidence suggests that the layered mafic Dufek Intrusion, towards the southern end of the Weddell Sea Rift System, was emplaced at this time (Burgess et al., 2015). The layered gabbroic intrusions in the Vestfjella area include two separate bodies up to $3 \mathrm{~km}$ thick (Vuori and Luttinen, 2003). The crosscutting relationship with the surrounding basalt flows indicate that they represent a later phase of the Karoo-Ferrar magmatic event, consistent with limited ${ }^{40} \mathrm{Ar} /{ }^{39} \mathrm{Ar}$ dating of feldspars which give an age of $177 \pm 1.8 \mathrm{Ma}$ (Zhang et al., 2003). A suite of mafic dikes running generally NE-SW parallel to the coast is also observed cutting the regionally extensive lavas in the Vestfjella area (Spaeth, 1987), however, dikes with a range of trends are observed further east in Dronning Maud Land (Curtis et al., 2008; Riley et al., 2005). The relatively broad age range of the dikes (206-175 Ma) indicates that although the emplacement of main Karoo-Ferrar lava and sill sequence was rapid there were significant magmatic precursors and follow up to the main magmatic event (Curtis et al., 2008; Jourdan et al., 2008; Riley et al., 2005).

\section{Methods}

\subsection{Data collection and enhancement}

The majority of the data presented in this paper was collected as part of a 2017 British Antarctic Survey (BAS) radar survey mapping the thickness of the Brunt Ice Shelf. The associated aeogravity and aeromagnetic data presented here provide important new insights into the subsurface geology of the region, especially important as the closest outcrop is $>200 \mathrm{~km}$ away. Additional line aerogeophysical data is taken from the margins of the ICEGRAV-2013 survey (Forsberg et al., 2017).

\subsubsection{Gravity data}

Gravity data during the Brunt 2017 survey was collected using an innovative strapdown gravity technique (Becker et al., 2016; Becker et al., 2015). This technique was first developed in the 
1990s (Wei and Schwarz, 1998) but advances in sensor design and data processing have only recently made this a viable method for field data collection. The key advantage of the strapdown gravity system is that it is relatively insensitive to the flight trajectory, hence data could be collected during all parts of the flight (Fig. 2). The inertial measurement unit (IMU) used was an iMAR RQH1003 system, consisting of three Honeywell QA2000 accelerometers (mounted in mutually perpendicular directions), and three Honeywell GG1230 ring laser gyroscopes.

An 18-state Kalman filter in conjunction with a Rauch-Tung-Striebel (RTS) smoother was used to process the strapdown gravity data. Besides the 15 states of a typical IMU/GNSS integrating Kalman filter used for navigation (3-D position, velocity, attitude, and six inertial sensor biases), additional states were used to model the gravity disturbance with respect to GRS80 normal gravity. GPS coordinates were processed with a standard precise point positioning software package (Novatel Waypoint GrafNav 8.60), and introduced as observations to the Kalman filter. The Kalman filter (and RTS smoother) provides gravity estimates in a one-step evaluation, i.e. no additional lowpass filtering step is required. This method is sometimes referred to as the indirect method of strapdown gravimetry, because gravity is determined indirectly by introducing GNSS positions to the Kalman filter, rather than computing GNSS accelerations in a pre-processing step and manually combining them with the specific forces measured by the accelerometers in order to determine gravity. The indirect approach is theoretically more rigorous as combining all information into a single system model enables optimal estimation. However, recently a systematic comparison of the two approaches on various data sets indicated no significant differences between the two approaches. However, we prefer the indirect method in general, as it allows the usage of standard system analysis tools (observability, estimability) and a simple and optimal integration of additional sensors and external information, where available.

To minimise thermal effects on the QA2000 accelerometers, the IMU was warmed up for at least two hours before each flight. However, a further thermal correction was applied to 
compensate reproducible thermal effects arising from internal sensor temperature changes along the flights. Details on the strapdown gravity data processing and the thermal calibration methods can be found in (Becker, 2016). Processed line gravity data is freely available from the UK Polar Data Centre (Becker et al., 2018).

The optimum resolution of the strapdown gravity system is approximately 100 seconds along-track, consistent with a full wavelength spatial resolution for the 2017 Brunt survey of $\sim 6 \mathrm{~km}$ (at an aircraft speed of approximately $60 \mathrm{~m} / \mathrm{s}$ ). This result is supported by a power spectrum of the gravity data (Fig. 3b) which indicates the signal is well above the noise floor by a wavelength of $6 \mathrm{~km}$. The standard deviation of the strapdown gravity crossover errors was $2.5 \mathrm{mGal}$, consistent with a root-mean-square error of 1.8 mGal. The previous ICEGRAV-2013 campaign (Fig. 2) used a standard LaCoste and Romberg air-sea gravity sensor in a stabilised platform, limiting data collection to straight and level flight sections (Forsberg et al., 2017; Jordan et al., 2007). The standard deviation of the crossover errors for the ICEGRAV 2013 survey was 3.9 mGal (Forsberg et al., 2017). Data from a regional compilation (Jordan et al., 2017), including digitised contour maps of Russian gravity data (Aleshkova et al., 1997), was used to inform the regional field where no other data was available. To visualise the gravity anomaly across the entire study region a unified free air gravity anomaly grid was constructed (Fig. 3a) (See Sup. Mat. Section S1 for compilation details).

A significant component of the observed free air anomaly is due to the bathymetry. To account for this we calculated the Bouguer gravity correction, using data from BEDMAP2 (Fretwell et al., 2013), augmented with seismic data over the ice shelf and swath bathymetry for offshore regions and areas where the ice shelf had previously calved (Hodgson et al., 2018) (Fig. 2 and 4a). The full 3D Bouguer correction, was modelled using a 3D Gauss-Legendre quadrature (GLQ) method (von Frese et al., 1981), assuming a uniform observation altitude of $450 \mathrm{~m}$, coincident with the 2017 survey altitude over the ice shelf. Results onshore, where the aircraft altitude and ice surface were $>450 \mathrm{~m}$, are not valid. A more complex model including a variable observation surface would be required to 
calculate corections over both ice shelf and onshore regions, but was not justified in this case as the onshore area lies outside our key area of intrest. Standard densities for the Bouguer correction of 915,1028 and $2670 \mathrm{kgm}^{-3}$ for ice, water and rock respectively were used. The resulting Bouguer anomaly shows a strong regional trend across the survey region (Fig. 4b). The regional signal in the Bouguer anomaly was isolated using a $150 \mathrm{~km}$ low pass filter (Fig. 4c). This wavelength was chosen because it removes the long wavelength trend in the data, but does not apear to impact the peak to trough amplitude of the local gravity anomalies. The long wavelength regional signal was subtracted from the Bouguer anomaly to reveal the final residual gravity anomalies (Fig. 4d).

\subsubsection{Aeromagnetic data}

Aeromagnetic data for both the Brunt 2017 and ICEGRAV-2013 surveys was collected using the BAS aerogeophysically equipped Twin Otter aircraft (See Sup. Mat. Section S2 for processing details). The line data was continued to an altitude of $500 \mathrm{~m}$ and interpolated onto a $1 \mathrm{~km}$ mesh. The ADMAP dataset was used to pad the surrounding regions (Golynsky et al., 2001). Finally the gridded magnetic compilation was reduced to the magnetic pole (RTP) (Fig. 5) to ensure anomalies overlie their sources (Baranov and Naudy, 1964). Processed line aeromagnetic data for the 2017 survey is freely available from the UK Polar Data Centre (Jordan et al., 2018).

To further define the boundaries of magnetic sources and their depths we calculated the maximum horizontal gradient of pseudo-gravity, tilt angle, tilt depth estimates and 3D extended Euler deconvolution depth estimates. These enhancements focused over the region where the highest resolution data was available (Fig. 6). Peaks in the maximum horizontal gradient of pseudogravity typically reveal the edges of deeper and more regional sources (Fig. 6a) (Blakely and Simpson, 1986; Cordell and Grauch, 1985), see Sup. Mat. Section S3 for details of calculation. The tilt angle highlights short wavelength lower amplitude anomalies (Fig. 6b) and can determine both the depth and position of anomaly source margins (Fig. 6c) (Cooper and Cowan, 2006; Miller and 
Singh, 1994; Salem et al., 2007; Salem et al., 2010). Details of tilt angle calculation and the threshold tilt depth determination method are in Sup. Mat. Section S4.

The 3D extended Euler depth estimates (Fig. 6d) were calculated following standard techniques (Nabighian and Hansen, 2001; Reid et al., 1990) using programs provided by the US Geological Survey (Philips, 2007). A range of analysis window sizes, acceptable levels of error and potential source geometries (structural index) were considered. A window size of $7 \mathrm{~km}$, error tolerance of $10 \%$ and a structural index of zero (an infinite contact source) appears to give the most reasonable clustering and number of extended Euler solutions (Fig. 6d). Such parameters are consistent with the 5 to $10 \mathrm{~km}$ wavelengths of many of the anomalies beneath the Brunt Ice Shelf. In addition the 3D extended Euler solutions cluster near the margins of the source bodies indicated by the maximum horizontal gradient of pseudo-gravity (Fig. 6a) and approximately match the location and depth estimates from the tilt angle analysis (Fig. 6c). It is apparent that the Euler results show generally deeper solutions in the northern part of the 2017 survey area, however, line spacing in this region is significantly wider (Fig. 2) and hence this result may be an artefact.

\subsection{D geophysical model setup}

To further investigate the origin of the observed gravity and magnetic anomalies over the Brunt Ice Shelf we constructed 2.5D joint gravity and magnetic models using the Geosoft GMSYS software package (Fig. 7). Uncertainties in susceptibility, density and absolute source depth mean a detailed model precisely fitting the data is not justified. Instead, we aim to provide a reasonable match to the observed data using bodies with simple geometries and reasonable geophysical properties, allowing interpretation and discussion of the underlying geology. Data for the models was sampled from $500 \mathrm{~m}$ rasters of the Brunt 2017 survey magnetic and gravity data, to ensure only the highest quality data was used and short wavelength anomalies were captured. The long wavelength crustal gravity field revealed by low pass filtering the Bouguer anomaly (Fig. 4c) was subtracted from the free air gravity anomaly prior to modelling so that the modelled anomaly 
contains only gravity signals from shallower crustal levels and bathymetry. Magnetic depth to source solutions (Fig. $6 \mathrm{c}$ and d) within $5 \mathrm{~km}$ of the modelled profiles were projected onto the models and, together with the maps of the maximum horizontal gradient of pseudo-gravity and tilt contours, were used to guide the approximate placement of bodies. The impact of uncertainties in bathymetry, density and susceptibility was also investigated (Supplementary figures S1 and S2). The standard assumption of an infinite body extending across strike is valid for the N-S profile (A-A'), however, the E-W profile (B-B') runs along strike of the modelled gravity high (Fig. 4d). Hence, for the $\mathrm{E}-\mathrm{W}$ model a $2.5 \mathrm{D}$ assumption was made with the modelled bodies extending between 10 and $15 \mathrm{~km}$ each side of the profile (Fig. 7b).

\section{Results and interpretation:}

\subsection{Gravity and magnetic signatures}

The free air gravity anomaly shows two significant highs in the region of the Brunt Ice Shelf (Fig. 3a). The northernmost Shelf Break High (SBH) correlates well with the continental shelf break in bathymetric data (Fig. 4a), and is a typical feature of continental margins around the world e.g. (Watts and Stewart, 1998). The second gravity high, we name the Halley High, lies $\sim 30 \mathrm{~km}$ north of the Halley VI research station. The Bouguer anomaly (Fig. 4b) does not indicate a localised SBH anomaly, instead showing a strong regional north to south gradient across the study area (Fig. 4c), which we attribute to the variation in crustal thickness from the East Antarctic continent across the continent-ocean transition. The residual gravity anomaly (Fig. 4d) does not show the elongated $>50$ mGal SBH anomaly, indicating the SBH is adequately explained by a combination of bathymetric and long wavelength crustal gravity effects. In contrast, the Halley High is revealed as the most significant anomaly beneath the Brunt Ice Shelf, with an amplitude of up to $52 \mathrm{mGal}$. Other more minor gravity anomalies are attributed to uncertainties in the bathymetry, un-modelled geology, or lack in resolution in the gravity data outside the central study area. 
The aeromagnetic data over the Brunt Ice Shelf reveals a series of NW-SE trending anomalies (Fig. 5), which are further highlighted by the pseudo-gravity and tilt enhancements (Fig. 6a and b). The broadest anomalies, E1 and E2, have amplitudes of 500-800 nT and correspond to magnetic anomalies identified by previous workers (Mieth and Jokat, 2014). Our data also reveals for the first time a series of 5-8 km wavelength 30-50 nT anomalies southeast of the Halley Research Station, which are parallel to the NW-SE regional trends (Figs. 5 and 6). The full extent of these lower amplitude anomalies cannot be constrained as they are only identified in the highest resolution Brunt 2017 survey. To the south of the study area magnetic anomalies with amplitudes of $+/-350 \mathrm{nT}$ are noted with wavelengths of $\sim 25 \mathrm{~km}$ (Fig. 5); we attribute these signatures to the previously identified cratonic Coats Land Block (Studinger and Miller, 1999). Both the regional and shorter wavelength NW-SE trending anomalies appear to terminate to the north west of the survey area (Fig. 5). In some cases this is associated with the edge of the Brunt 2017 survey data, and hence the termination of the anomalies is not well resolved. However, in the region of the Halley High gravity anomaly two distinct magnetic anomalies with amplitudes of 400 to $1000 \mathrm{nT}$ are observed in our new higher resolution aeromagnetic data. These anomalies appear to crosscut the NW-SE regional trend, a pattern confirmed by the pseudo-gravity and tilt enhancements (Fig. 6a and b). A significant 300 nT magnetic anomaly in the region of the Halley High was reported by previous workers (Golynsky and Aleshkova, 1997). However, the previously available data did not reveal the full amplitude, the two parts of the anomaly, or constrain the boundaries of this body, which are now well resolved at least to the south and east.

\subsection{D potential field modelling}

We model the Halley High gravity anomaly as a dense subsurface body with high magnetic susceptibility (Fig. 7). Modelling of the gravity data along the N-S profile (A-A') shows that bathymetric variations cannot account for the observed anomaly (Supplementary Fig. S1a). Further tests of the gravity models along profile $\mathrm{A}-\mathrm{A}^{\prime}$ show that the dense body must be $\sim 30 \mathrm{~km}$ wide (Supplementary Fig. S1b), in line with magnetic estimates of the body width (Fig. 6a and c). Thickness 
and density of any body in a gravity model can be traded off against each other. Our tests indicate that varying the density between 2900 and $3100 \mathrm{kgm}^{-3}$ is approximately equivalent to varying the body thickness by $+/-1.5 \mathrm{~km}$ (Supplementary Fig. S1c and d) and we consider this a reasonable estimate of the uncertainty of the source body thickness. A modelled body $<3 \mathrm{~km}$ thick with a density of $3000 \mathrm{kgm}^{-3}$ gives an anomaly with an amplitude $\sim 55 \%$ of what is observed, and would require unrealistically high densities $\left(>3100 \mathrm{kgm}^{-3}\right)$ to fit the data (Supplementary Fig. S1b).

Further tests show that if the entire $30 \mathrm{~km}$ wide dense block had uniform magnetic properties then no susceptibility value is able to fit the pattern and amplitude of the observed magnetic anomaly (Supplementary Fig. S2a). In contrast if the magnetic source body was only $\sim 8 \mathrm{~km}$ wide the amplitude of the anomaly could be matched, but the longer wavelength pattern is not well modelled (Supplementary Fig. S2b). We therefore propose that there is a high susceptibility 'core' within the source body, flanked by lower, but non zero, susceptibility margins. This would be consistent with the map view of the magnetic data and the digital enhancements that show a more complex magnetic structure with at least two discrete magnetic anomalies within the region of the Halley High (Fig. 5 and 6).

Overall, given the shallow depth to source solutions, we model the source body on the N-S profile as a dense and highly magnetic block $6 \mathrm{~km}$ thick and $30 \mathrm{~km}$ wide, extending to a depth of 7 $\mathrm{km}$. The assumed density of the body is $3000 \mathrm{kgm}^{-3}$, with susceptibilities of up to $0.08 \mathrm{SI}$ for the core and between 0.01 and $0.04 \mathrm{SI}$ for the margins. On the E-W profile a body with the same density and thickness over-estimates the amplitude of the observed gravity anomaly, despite using a 2.5D model. We attribute this to incomplete modelling of the shallow 3D structure of the body. The susceptibility along the E-W profile is more variable, with two higher susceptibility sections $(0.05 \mathrm{SI}$, and $0.08 \mathrm{SI}$ ) accounting for the two most significant magnetic anomalies. 


\subsection{Interpretation}

The regional NW-SE trend in the aeromagnetic data, including major anomalies E1 and E2 (Fig. 8a) is similar to the structural trend seen in the 1 Ga Grenville age Maud Belt (Golynsky and Jacobs, 2001; Mieth and Jokat, 2014) to the northeast of the study area (Fig. 8b). The crust in this region is composed of high-grade metamorphic rocks and post tectonic granites (Jacobs, 2009). Magnetic anomalies E1 and E2 were noted by previous workers (Mieth and Jokat, 2014) and linked to the Beattie Magnetic Anomaly (BMA) in southern Africa, which is thought to reflect crust of the 1Ga Namaqua-Natal Maud Belt composed of granitic gneisses (Lindeque et al., 2011). We show that anomalies E1 and E2 are not associated with clear positive gravity anomalies, hence there is little density contrast between the magnetic sources and the surrounding rocks, a similar situation to the BMA (Mieth and Jokat, 2014). Together the match to the Maud Belt trend and lack of associated gravity anomalies lead us to interpret anomalies E1 and E2 as magnetic provinces within Grenvillian basement. We speculate that these anomalies are the result of arc magmatic provinces accreted, together with intervening less magnetic meta-sedimentary packages, to the margin of the Grunehogna Craton during the Grenville orogeny (Jacobs et al., 2008). This interpretation implies the Maud Belt is up to $500 \mathrm{~km}$ wide and extends to the southern edge of our study area where the previously identified rigid Coats Land Block formed of $>1$ Ga crystalline basement is inferred (Golynsky and Aleshkova, 1997; Studinger and Miller, 1999).

The origin of the lower amplitude NW-SE trending magnetic anomalies southeast of Halley Research Station is more ambiguous (Fig. 8a). Their trend is parallel to the interpreted basement structures E1 and E2, and the sources could therefore be magnetic volcanic sequences folded within a less magnetic Grenville age meta-sedimentary province. An alternative explanation is that these narrow linear anomalies reflect later (Jurassic?) dikes exploiting structural weaknesses in the basement. The trends of these anomalies are oblique to the dominant trends of exposed Jurassic dikes seen in Vestfjella (Spaeth, 1987), and the Jutulstraumen region (Curtis et al., 2008; Riley et al., 2005) (Fig. 8b). In addition the exposed dikes are typically 1-80 m wide (Riley et al., 2005; Spaeth, 
1987), and hence would not be expected to be well resolved by a $5 \mathrm{~km}$ line spacing aeromagnetic survey. However, the amplitude and wavelength of these anomalies are similar to that of anomalies attributed to Jurassic dikes around the Dufek intrusions (Ferris et al., 2003). Ultimately, further detailed aeromagnetic surveys in this region are required to trace these anomalies and to determine their distribution and origin.

The Halley High gravity and magnetic anomalies reflect the most significant geological structure within the survey region (Fig. 8a). The close correspondence of the positive gravity anomaly with the highest amplitude magnetic anomalies in our study region indicates that a single geological source is likely responsible for both the gravity and magnetic anomalies (Fig. 4d and 5). The successful joint magnetic and gravity models (Fig. 7) support the interpretation of a unified gravity and magnetic source. The pattern of coincident positive gravity and magnetic anomalies is unlike that seen over the interpreted basement structures E1 and E2, and ENE-WSW trend of the Halley High also differs from the regional basement grain. We therefore interpret the Halley High gravity and magnetic anomalies as a single feature resulting from a body distinct from the other sources in the study area.

The broad trend of the Halley High approximately parallels the offshore magnetic Explora Anomaly, and the trend of the ocean continent-transition (Fig. 8). This pattern leads us to propose a Jurassic magmatic source for the observed anomaly, in line with the suggestions of previous authors (Golynsky and Aleshkova, 1997). The modelled high density $\left(\sim 3000 \mathrm{kgm}^{-3}\right)$ and susceptibility (up to $0.008 \mathrm{SI}$ ) lead us to interpret the source to be a mafic body. Both a localised rift basin filled with basalts, and a gabbroic intrusion could give rise to the observed anomalies. However, the magnetic signatures and associated digital enhancements over the Halley High, together with the 2.5D models indicate that, from a magnetic perspective, this structure is a composite body with outward dipping sides. This would seem to support an intrusive interpretation for the source body, as a localised rift basin would be expected to have inward dipping margins. Furthermore, a multi-part intrusion would 
be consistent with observations in the Vestfjella area where gabbroic intrusions with distinct susceptibilities are emplaced just $25 \mathrm{~km}$ apart. The overall modelled densities are within the range of values measured in the Vestfjella gabbros (Vuori and Luttinen, 2003). The susceptibilities required to match the observed anomalies are relatively high for a typical gabbro (Telford et al., 1990), however, they are within the range of values recovered for the Vestfjella gabbros (Vuori and Luttinen, 2003) supporting our interpretation that the Halley High reflects an intrusive mafic source. A similar pattern of a coupled gravity and magnetic high is also seen and modelled to reflect mafic intrusions in the near-shore parts of the Explora Anomaly further north in Dronning Maud Land (Leitchenkov et al., 1996).

Our interpretation that the Halley High is due to a mafic intrusion $30 \mathrm{~km}$ wide, $80 \mathrm{~km}$ long and $\sim 6 \mathrm{~km}$ thick is consistent with the form and geophysical signatures of many large layered mafic intrusions around the world. The closest analogue in terms of size is the Stillwater complex in the US. This elongate body has a surface exposure of $\sim 47$ by $8 \mathrm{~km}$, and a stratigraphic thickness of $\sim 6 \mathrm{~km}$ (McCallum, 2002). However, positive gravity anomalies of 30-50 mGal indicate a larger buried body $70 \mathrm{~km}$ long and $30 \mathrm{~km}$ wide and 3-8 km thick (Bonini, 1982; Finn et al., 2013). The Dufek intrusion to the south of our survey area is also on a similar scale, $~ 50 \mathrm{~km}$ wide and $100 \mathrm{~km}$ long, with magnetic anomalies of $>1000 \mathrm{nT}$ (Ferris et al., 1998). The Bushveld complex in South Africa, at over $400 \mathrm{~km}$ wide, is much larger than the Halley High. However, the 40 to $70 \mathrm{mGal}$ amplitude of the Bushveld complex gravity anomalies, modelled to be due to a body 5-8 km thick (Kgaswane et al., 2012), are similar to the amplitude we observe over the Halley High. The high amplitude magnetic anomalies of $>1000 \mathrm{nT}$ seen over parts of the Bushveld complex are also in line with what we observe (Cole et al., 2013). 


\section{Discussion}

The location of mantle melting has significant implications for understanding the mechanisms driving magmatism at the onset of Gondwana breakup. Recognition of the large $80 \times 30 \times 6$ km Halley High Jurassic gabbro beneath the Brunt Ice Shelf (Fig. 8a) , together with the outcropping gabbros $\sim 300 \mathrm{~km}$ away in Vestfjella (Vuori and Luttinen, 2003), supports previous aeromagnetic interpretation of a suite of Jurassic mafic magmatic bodies along the margin of Dronning Maud Land and Coats Land (Golynsky and Aleshkova, 1997; Leitchenkov et al., 1996) (Fig. 8b). This suite of intrusions has an average spacing of $\sim 128 \mathrm{~km}$ and lies approximately parallel to the dominant trend of outcropping mafic dikes in this region (Riley et al., 2005; Spaeth, 1987). Overall the band of intrusions parallels the magnetic Explora Anomaly (Johnson et al., 1992) and structures within the Northern Weddell Magnetic Province (Jordan et al., 2017) (Fig. 8b). These two offshore structures are interpreted as reflecting an extensive seaward dipping reflector sequence and breakup related magmatism generated as the Gondwanan plates finally began to move apart (Johnson et al., 1992; Jordan et al., 2017; Kristoffersen and Hinz, 1991; Kristoffersen et al., 2014). The close association between the onshore intrusive rocks, the inferred seaward dipping reflector sequence and the trend of the continental margin suggests that lithospheric extension and continental breakup likely played a significant role in the generation and emplacement of these magmas.

We note that there is a significant gap between the band of continental margin mafic intrusions and the Dufek Intrusion $\sim 650 \mathrm{~km}$ to the south (Fig. 8b). The gap may reflect sparse data coverage, however, it is surprising no mafic bodies have been identified given their recognition further north from similar reconnaissance data sets (Golynsky and Aleshkova, 1997). The apparent gap in mafic magmatism is adjacent to the distinct Southern Weddell Magnetic Province, which is inferred to be a region of back-arc continental extension (Jordan et al., 2017). Modelled intrusions in this region are not associated with positive gravity anomalies that would be expected to characterise mafic bodies (Jordan et al., 2017). We suggest this gap indicates that the mantle processes occurring 
here did not lead to the generation or emplacement of significant mafic intrusions in the upper crust. The location of the Dufek Intrusion far from the other mafic intrusions suggests that it reflects a separate phase of magmatism, unrelated to the mafic intrusions further north.

The timing of magmatism within the Halley High, or the other intrusions along the continental margin, cannot be constrained by geophysical methods alone. Geological relationships show that the Vestfjella gabbros post-date the local LIP basalts, which they crosscut (Vuori and Luttinen, 2003). This crosscutting relationship is also seen in the coast parallel dikes in the Vestfjella area (Spaeth, 1987). Direct ${ }^{40} \mathrm{Ar} /{ }^{39} \mathrm{Ar}$ dating of the Utpostane gabbro in Vestfjella gives an age of $\sim 177 \mathrm{Ma}$ (Zhang et al., 2003), similar to the $178 \mathrm{Ma}$ age of many of the coast parallel dikes in the Jutulstraumen region (Riley et al., 2005). Assuming the interpreted suite of large intrusions and dikes emplaced along the continental margin are coincident, the geological relationships and dating suggests that they likely post-date the short lived 183 Ma pulses of magma which gave rise to most of the Karoo sills in South Africa (Svensen et al., 2012), and the Ferrar lavas in Antarctica (Burgess et al., 2015). The 182.7 Ma age of the Dufek Intrusion, coincident with the wider Ferrar Magmatism (Burgess et al., 2015) supports our previous suggestion, based on the distribution of intrusions, that this in-board intrusion is distinct from the continental margin intrusions further north. Dating of the Karoo magmas on the conjugate South African margin, including the large Mount Ayliff gabbro complex, give a dominant age of $\sim 183$ Ma indicating the majority of magmatism on this margin preceded the breakup magmatism we interpret (Jourdan et al., 2008; Svensen et al., 2012). Some sills and suites of dikes in Southern Africa do, however, give younger ages of 176-178 Ma (Jourdan et al., 2008; Riley et al., 2006), indicating a secondary pulse of magmatism, similar to what we envisage, also occurred in Southern Africa. This secondary pulse of magmatism in Southern Africa is attributed to strong extension associated with continual breakup (Jourdan et al., 2008), which would be consistent with our model for the magmatic evolution of the Antarctic continental margin. 
The presence of a band of large mafic intrusions along the Antarctic continental margin is a situation directly analogous to the Greenland sector of the North Atlantic Igneous Province (Brooks, 2011). Dating of the large mafic intrusions along the Greenland margin indicates two pulses of intrusive magmatism at 57-54 Ma and 50-47 Ma which post-dated the initial 62-59 Ma lavas and dikes (Tegner et al., 1998). This pattern is suggested to reflect the distinct mantle melting episodes associated with initial plume impact, and subsequent continental breakup and passage of the plume tail (Tegner et al., 1998). Further analysis and modelling of the main intrusive centres along the Greenland margin has led to the suggestion that small scale convection in the upper mantle, rather than the impact of a single large mantle-scale plume, played a significant role in determining the location of mantle melting and associated magmatism (Callot et al., 2002; Geoffroy et al., 2007). The similarity in both relative timing and spatial pattern of magmatism along the Greenland and Coats Land/Dronning Maud Land margins leads us to suggest these margins are analogous. Hence, we propose a model where plume impact leading to shallow level magmatism, followed by emplacement of larger mafic intrusions controlled by small-scale convection and thinning of the lithosphere due to continental rifting, best explains the magmatic evolution of Gondwana as it began to break up.

\section{Conclusions}

We interpret detailed aerogeophysical data as showing a coupled gravity and magnetic high, called the Halley High, caused by a large mafic body approximately $80 \mathrm{~km}$ long, $30 \mathrm{~km}$ wide and $6 \mathrm{~km}$ thick, with a volume of $\sim 12,000 \mathrm{~km}^{3}$. Emplacement of this body into the margin of the East Antarctic continent, was part of the wider Karoo-Ferrar LIP. This work demonstrates how new strapdown gravity techniques coupled with high resolution aeromagnetic data provide a critical tool for understanding sub-surface geology where outcrop is limited or absent, as in the ice covered Antarctic continent. 
Our analysis and interpretation of the Halley High as a Jurassic mafic intrusion supports previous regional aeromagnetic interpretations of a linear belt of mafic intrusions along the margin of Coats Land and Dronning Maud Land. We take these intrusions to be a more robust marker of the locations of mantle melting than shallower, potentially far travelled magmas within sills or volcanic flows. The distribution of these large mafic intrusions parallel with both the continental margin and inferred offshore seaward dipping reflector sequences, together with an inferred age $\sim 5$ Ma younger than the shallow Karoo-Ferrar lavas, is similar to that seen on the better-known Greenland volcanic margin. We interpret this pattern as indicating that shallow mantle convection and lithospheric extension associated with continental breakup played an important role in determining where the mantle melting giving rise to these intrusions occurred.

$A \sim 650 \mathrm{~km}$ gap in mafic intrusions between the continental margin and the distinct Dufek Intrusion leads us to hypothesise that upper mantle processes leading to generation and emplacement of mafic magmas were absent in this region. However, further detailed aerogeophysical investigations are required to accurately determine the true extent of mafic magmatism and hence mantle melting along this sector of the Gondwanan margin.

\section{Acknowledgements}

Data for this paper was collected as part of the NERC/BAS Life Time of Halley project, and interpretation supported by the BAS Geology and Geophysics team. We thank Hugh Corr, Carl Robinson, the BAS air unit and staff at Halley Research Station for their support of the 2017 field campaign. Finally we thank Phil Leat and Teal Riley for their helpful discussions on Jurassic magmatism.

\section{References}

Aleshkova, N.D., Golynsky, A.V., Kurinin, R.G., Mandrikov, V.S., 1997. Gravity mapping in the Southern Weddell Sea Region. (Explanatory note for free-air and Bouguer anomalies maps). Polarforschung 67, 163-177. Baranov, V., Naudy, H., 1964. Numerical Calculation of the Formula of Reduction to the Magnetic Pole. Geophysics 29, 67-79 http://dx.doi.org/10.1190/1191.1439334. 
Becker, D., 2016. Advanced calibration methods for strapdown airborne gravimetry. Technische Universität Darmstadt.

Becker, D., Becker, M., Olesen, A.V., Nielsen, J.E., Forsberg, R., 2016. Latest results in strapdown airborne gravimetry using an iMAR RQH unit., 4th IAG Symposium on Terrestrial Gravimetry: Static and Mobile Measurements. State Research Center of the Russian Federation., Saint Petersburg, Russian Federation, pp. 19-25.

[dataset] Becker, D., Jordan, T.A., Corr, H., Robinson, C., 2018. Strapdown gravity survey across the Brunt Ice Shelf (2017) UK Polar Data Center https://doi.org/10.5285/79e63097-f5dc-41ff-8ca536bc4f95a6ff.

Becker, D., Nielsen, J.E., Ayres-Sampaio, D., Forsberg, R., Becker, M., Bastos, L., 2015. Drift reduction in strapdown airborne gravimetry using a simple thermal correction. Journal of Geodesy 89, 11331144.

Behrendt, J.C., Drewry, D.J., Jankowski, E.J., Grim, M.S., 1981. Aeromagnetic and Radio Echo IceSounding Measurements over the Dufek Intrusion, Antarctica. Journal of Geophysical Research 86, 3014-3020.

Blakely, R.J., Simpson, R.W., 1986. Approximating edges of source bodies from magnetic or gravity anomalies. Geophysics 51, 1494-1498.

Bonini, W.E., 1982. The size of the Stillwater complex: an estimate from gravity data, in: Walker, D., McCallum, I.S. (Eds.), Magmatic Processes of Early Planetary Crusts: Magma Oceans and Stratiform Layered Intrusions. Lunar and Planetary Institute, 3303 NASA Road 1, Houston, TX 77058, p. 53.

Brooks, C.K., 2011. The east Greenland rifted volcanic margin. Geological Survey of Denmark and Greenland Copenhagen.

Burgess, S.D., Bowring, S.A., Fleming, T.H., Elliot, D.H., 2015. High-precision geochronology links the Ferrar large igneous province with early-Jurassic ocean anoxia and biotic crisis. Earth and Planetary Science Letters 415, 90-99.

Callot, J.-P., Geoffroy, L., Brun, J.P., 2002. Development of volcanic passive margins: Threedimensional laboratory models. Tectonics 21, doi:10.1029/2001TC901019.

Cole, J., Finn, C.A., Webb, S.J., 2013. Overview of the magnetic signatures of the Palaeoproterozoic Rustenburg Layered Suite, Bushveld Complex, South Africa. Precambrian Res. 236, 193-213.

Cooper, G.R.J., Cowan, D.R., 2006. Enhancing potential field data using filters based on the local phase. Computers \& Geosciences 32, 1585-1591.

Cordell, L.E., Grauch, V.J.S., 1985. Mapping basement magnetization zones from aeromagnetic data in the San Juan Basin, New Mexico, in: Hinze, W.J. (Ed.), The utility of regional gravity and magnetic anomaly maps. Society of Exploration Geophysicists, pp. 181-197.

Corner, B., 1994. Geological evolution of western Dronning Maud Land within a Gondwana framework, Geophysics subprogramme. Final project report to SCAR. Witwaterstrand University, South Africa: Department of Geophysics,, p. 21.

Curtis, M.L., Riley, T.R., Owens, W.H., Leat, P.T., Duncan, R.A., 2008. The form, distribution and anisotropy of magnetic susceptibility of Jurassic dykes in H.U. Sverdrupfjella, Dronning Maud Land, Antarctica. Implications for dyke swarm emplacement. Journal of Structural Geology 30, 1429-1447. Dalziel, I.W.D., Lawver, L., Norton, I.O., Gahagan, L.M., 2013. The Scotia Arc: Genesis, Evolution, Global Significance. Annual Review of Earth and Planetary Sciences 41, 767-793.

Elliot, D.H., 1992. Jurassic magmatism and tectonism associated with Gondwanaland break-up: an Antarctic perspective, in: Storey, B.C., Pankhurst, R.J. (Eds.), Magmatism and the Causes of Continental Break-up. Geological Society, London, Special Publication pp. 165-184, doi: 110.1144/ GSL.SP.1992.1068.1101.1111

Elliot, D.H., Fleming, T.H., 2000. Weddell triple junction: The principal focus of Ferrar and Karoo magmatism during initial breakup of Gondwana. Geology 28, 539-542, doi: 510.1130/00917613(2000)1128<1539:WTJTPF>1132.1130.CO;1132.

Elliot, D.H., Fleming, T.H., Kyle, P.R., Foland, K.A., 1999. Long-distance transport of magmas in the Jurassic Ferrar large igneous province, Antarctica. Earth and Planetary Science Letters 167, 89-104. 
Ferraccioli, F., Jones, P.C., Curtis, M.L., Leat, P.T., 2005. Subglacial imprints of early Gondwana breakup as identified from high resolution aerogeophysical data over western Dronning Maud Land, East Antarctica. Terra Nova 17, 573-579.

Ferris, J.K., Johnson, A.C., Storey, B.C., 1998. Form and extent of the Dufek intrusion, Antarctica, from newly compiled aeromagnetic data Earth and Planetary Science Letters 154, 185-202 Ferris, J.K., Storey, B.C., Vaughan, A.P.M., Kyle, P.R., Jones, P.C., 2003. The Dufek and Forrestal intrusions, Antarctica: A centre for Ferrar Large Igneous Province dike emplacement? Geophysical Research Letters 30, doi:10.1029/2002GL016719.

Finn, C.A., Zientek, M.L., Bloss, B.R., Wintzer, N.E., Parks, H.L., 2013. Geophysical imaging of the Stillwater Complex and relation to platinum group element exploration, Geological Society of America, 2013 Annual Meeting, pp. Paper No. 109-106.

Ford, A.B., Himmelberg, G.R., 1991. Geology and crystallization of the Dufek intrusion, in: Tingey, R.J. (Ed.), The Geology of Antarctica. Clarendon Press, Oxford, pp. 175-214.

Forsberg, R., Olesen, A.V., Ferraccioli, F., Jordan, T., Matsuoka, K., Zakrajsek, A.F., Ghidella, M.E., Greenbaum, J.S., 2017. Exploring the Recovery Lakes region and interior Dronning Maud Land, East Antarctica, with airborne gravity, magnetics and radar measurements, in: Siegert, M.J., Jamieson, S.S.R., White, D.A. (Eds.), Exploration of Subsurface Antarctica: Uncovering Past Changes and Modern Processes. Geological Society, London, Special Publications,, London.

Fretwell, P., Pritchard, H.D., Vaughan, D.G., Bamber, J., Barrand, N., Bell, R., Bianchi, C., Bingham, R., Blankenship, D., Casassa, G., 2013. Bedmap2: improved ice bed, surface and thickness datasets for Antarctica. The Cryosphere 7.

Geoffroy, L., Aubourg, C., Callot, J.-P., Barrat, J.-A., 2007. Mechanisms of crustal growth in large igneous provinces: The north Atlantic province as a case study,, in: Foulger, G.R., Jurdy, D.M. (Eds.), Plates, plumes, and planetary processes. Geological Society of America Special Paper, pp. 747-774, doi: 710.1130/2007.2430(1134).

Golynsky, A., Aleshkova, N.D., 1997. Regional magnetic anomalies of the Weddell Sea Region and their geological significance. Polarforschung 67, 101-117.

Golynsky, A., Chiappini, M., Damaske, D., Ferraccioli, F., Ferris, J.K., Finn, C., Ghidella, M.E., Isihara, T., Johnson, A., Kim, H.R., Kovacs, L., LaBrecque, J., Masolov, V., Nogi, Y., Purucker, M., Taylor, P., Torta, M., 2001. ADMAP - Magnetic Anomaly Map of the Antarctic, 1:10 000000 scale map, in: Morris, P., von Frese, R.R.B. (Eds.), BAS (Misc) 10. British Antarctic Survey, Cambridge. Golynsky, A., Jacobs, J., 2001. Grenville-Age versus Pan-African Magnetic Anomaly Imprints in Western Dronning Maud Land, East Antarctica. Journal of Geology 109, 136-142.

Hodgson, D.A., Hogan, K., Smith, J., Smith, J.A., Hillenbrand, C.D., Graham, A.G.C., Fretwell, P., Allen, C., Peck, V., Arndt, J.E., Dorschel, B., Hübscher, C., Smith, A.M., Larter, R., 2018. Deglaciation and future stability of the Coats Land ice margin, Antarctica. The Cryosphere Discuss. 2018, 1-28. Jacobs, J., 2009. A Review of Two Decades (1986 - 2008) of Geochronological Work in Heimefrontfjella, and Geotectonic Interpretation of Western Dronning Maud Land, East Antarctica. Polarforschung 79, 47-57.

Jacobs, J., Pisarevsky, S.A., Thomas, R.J., Becker, M., 2008. The Kalahari Craton during the assembly and dispersal of Rodinia. Precambrian Research 160, 142-158.

Jacobs, J., Thomas, R.J., 2004. Himalayan-type indenter-escape tectonics model for the southern part of the late Neoproterozoic-early Paleozoic East African- Antarctic orogen. Geology 32, 721-724, doi:710.1130/G20516.20511.

Johnson, A., Aleshkova, N.D., Barker, A., Golynsky, A.V., Masolov, V., Smith, A.M., 1992. A preliminary aeromagnetic anomaly compilation map for the Weddell province of Antarctica, in: Yoshida, Y. (Ed.), Recent Progress in Antarctic Earth Science Terra Scientific Publishing Company, Tokyo, pp. 545-553.

Jordan, T., Ferraccioli, F., Leat, P.T., 2017. New geophysical compilations link crustal block motion to Jurassic extension and strike-slip faulting in the Weddell Sea Rift System of West Antarctica.

Gondwana Research 42, 29-48, http://dx.doi.org/10.1016/j.gr.2016.1009.1009. 
[dataset] Jordan, T.A., Corr, H., Robinson, C., 2018. Aeromagnetic survey across the Brunt Ice Shelf (2017) UK Polar Data Center https://doi.org/10.5285/410ee2f9-2d22-4155-aaed-43b93a7c3d62. Jordan, T.A., Ferraccioli, F., Corr, H., Robinson, C., Caneva, G., Armadillo, A., Bozzo, E., Frearson, N., 2007. Linking the Wilkes Subglacial Basin, the Transantarctic Mountains, and the Ross Sea with a new airborne gravity survey, in: Bozzo, E., Ferraccioli, F. (Eds.), The Italian-British Antarctic Geophysical and Geological Survey in Northern Victoria Land 2005-06-Towards the International Polar Year 2007-08. Terra Antartica Reports, pp. 37-54.

Jourdan, F., Féraud, G., Bertrand, H., Kampunzu, A.B., Tshoso, G., Watkeys, M.K., Le Gall, B., 2005. Karoo large igneous province: Brevity, origin, and relation to mass extinction questioned by new 40Ar/39Ar age data. Geology 33, 745-748; doi: 710.1130/G21632.21631.

Jourdan, F., Feraud, G., Bertrand, H., Watkeys, M.K., Renne, P.R., 2008. The ${ }^{40} \mathrm{Ar} /{ }^{39} \mathrm{Ar}$ ages of the sill complex of the Karoo large igneous province: Implications for the Pliensbachian-Toarcian climate change. Geochemistry, Geophysics, Geosystems 9, doi:10.1029/2008GC001994.

Kgaswane, E.M., Nyblade, A.A., Durrheim, R.J., Julià, J., Dirks, P.H.G.M., Webb, S.J., 2012. Shear wave velocity structure of the Bushveld Complex, South Africa. Tectonophysics 554-557, 83-104, doi:110.1016/j.tecto.2012.1006.1003.

Kristoffersen, Y., Hinz, K., 1991. Evolution of the Gondwana plate boundary in the Weddell Sea area, in: Thompson, M.R.A., Crame, A., Thompson, J.W. (Eds.), Geological Evolution of Antarctica. Cambridge Univ. Press, Cambridge.

Kristoffersen, Y., Hofstede, C., Diez, A., Blenkner, R., Lambrecht, A., Mayer, C., Eisen, O., 2014. Reassembling Gondwana: A new high quality constraint from vibroseis exploration of the sub-ice shelf geology of the East Antarctic continental margin. Journal of Geophysical Research 119, doi:10.1002/2014JB011479.

Leat, P.T., 2008. On the long distance transport of Ferrar magmas, in: Thomson, K., Petford, N. (Eds.), Structure and Emplacement of High-level Magmatic Systems. Special Publication of the Geological Society, London, pp. 45-61.

Leitchenkov, G., Miller, H., Zatzepin, E.N., 1996. Structure and Mesozoic evolution of the eastern Weddell Sea, Antarctica: history of early Gondwana break-up, in: Storey, B.C., King, E.C., Livermore, R.A. (Eds.), Weddell Sea tectonics and Gondwana break-up. Geological Society of London, Special Publication, London, pp. 175-190.

Leitchenkov, G.L., Kudryavtzev, G.A., 1997. Structure and origin of the Earth's crust in the Weddell Sea Embayment (beneath the front of the Filchner and Ronne Ice Shelves) from deep seismic sounding data. Polarforschung $67,143-154$.

Lightfoot, P.C., Naldrett, A.J., 1983. The geology of the Tabankulu section of the Insizwa complex, Transkei, South African, with reference to the nickel sulphide potential. Trans. geol. Soc. S. Afr. 86, 169-187.

Lindeque, A., De Witt, M.J., Ryberg, T., Weber, M., L., C., 2011. Deep crustal profile across the southern Karoo Basin and Beattie Magnetic Anomaly, South Africa: Integrated interpretation with tectonic implications. S. Afr. J. Geol 114, 265-292, doi: 210.2113/gssajg.2114.2113-2114.2265. Luttinen, A.V., Leat, P.T., Furnes, H., 2010. Björnnutane and Sembberget basalt lavas and the geochemical provinciality of Karoo magmatism in western Dronning Maud Land, Antarctica. Journal of Volcanology and Geothermal Research 198, 1-18.

Marschall, H.R., Hawkesworth, C., Leat, P.T., 2013. Mesoproterozoic subduction under the eastern edge of theKalahari-Grunehogna Craton preceding Rodinia assembly: TheRitscherflya detrital zircon record, Ahlmannryggen (Dronning MaudLand, Antarctica). Precambrian Res. 236, 31-45, http://dx.doi.org/10.1016/j.precamres.2013.1007.1006.

McCallum, I.S., 2002. The Stillwater Complex: a review of the geology, 9th International Platinum Symposium, Geology and Guide Stillwater Complex, Montana, USA. Billings, pp. 21-25.

Mieth, M., Jokat, W., 2014. New aeromagnetic view of the geological fabric of southern Dronning Maud Land and Coats Land, East Antarctica. Gondwana Research 25, 358-367. 
Miller, H.G., Singh, V., 1994. Potential field tilt-a new concept for location of potential field sources. Journal of Applied Geophysicsl Prospecting, 213-217.

Nabighian, M.N., Hansen, R.O., 2001. Unification of Euler and Werner deconvolution in three dimensions via the generalized Hilbert transform. Geophysics 66, 1805-1810.

Philips, J.D., 2007. Geosoft eXecutables (GX's) Developed by the U.S. Geological Survey, Version 2.0, with Notes on GX Development from Fortran Code. USGS open file report 2007-1355.

Reid, A.B., Allsop, J.M., Granser, H., Millet, A.J., Somerton, I.W., 1990. Magnetic interpretation in three dimensions using Euler deconvolution. Geophysics 55, 80-91.

Riley, T.R., Curtis, M.L., Leat, P.T., Watkeys, M.K., Duncan, R.A., Millar, I.L., Owens, W.H., 2006. Overlap of Karoo and Ferrar Magma Types in KwaZulu-Natal, South Africa. Journal of Petrology 47, 541-566 https://doi.org/510.1093/petrology/egi1085.

Riley, T.R., Leat, P.T., Curtis, M.L., Millar, I.L., Duncan, R.A., Fazel, A., 2005. Early-Middle Jurassic Dolerite Dykes from Western Dronning Maud Land (Antarctica): Identifying Mantle Sources in the Karoo Large Igneous Province. Journal of Petrology 46, 1489-1524.

Ruotoistenmäki, T., Lehtimäki, J., 1997. Analysis of bedrock geology and thermal gradients using geophysical ground measurements on glaciated terrain in Queen Maud Land, Antarctica, in: Ricci, C.A. (Ed.), The Antarctic region: geological evolution and processes. Terra Antartica Publications, Siena, pp. 1149-1152.

Salem, A., Williams, S., Fairhead, J.D., Ravat, D., Smith, R., 2007. Tilt-depth method: a simple depth estimation method using first-order magnetic derivatives. The Leading Edge, 1502-1505.

Salem, A., Williams, S., Samson, E., Fairhead, J.D., Ravat, D., Blakely, R.J., 2010. Sedimentary basins reconnaissance using the magnetic Tilt-Depth method. Exploration Geophysics 41, 198-209.

Sander, B.K., Cawthorn, R.G., 1996. 2.5-D gravity model of the Ni-Cu-PGM mineralized Mount Ayliff Intrusion (Insizwa Complex), South Africa Journal of Applied Geophysics 35, 27-43.

Semenov, V.S., Mikhailov, V.M., Koptev-Dvornikov, E.V., Ford, A.B., Shulyatin, O.G., Semenov, S.V., Tkacheva, D.A., 2014. Layered Jurassic Intrusions in Antarctica. Petrology 22, 547-573.

Spaeth, G., 1987. Aspects of the structural evolution and magmatism in Western New Schwabenland, Antarctica, in: McKenzie, G.D. (Ed.), Gondwana Six: Structure, Tectonics and Geophysics. American Geophysical Union, Washington D.C., pp. 295-307.

Storey, B.C., 1995. The role of mantle plumes in continental breakup: case histories from Gondwanaland. Nature 377, 301-308.

Storey, B.C., Vaughan, A.P.M., Riley, T.R., 2013. The links between large igneous provinces, continental break-up and environmental change: evidence reviewed from Antarctica. Earth and Environmental Science Transactions of the Royal Society of Edinburgh 104, 1-14.

Studinger, M., Miller, H., 1999. Crustal structure of the Filchner-Ronne shelf and Coats Land, Antarctica, from gravity and magnetic data: Implications for the breakup of Gondwana. Journal of Geophysical Research 104, 20379-20394.

Svensen, H., Corfu, F., Polteau, S., Hammer, $\varnothing$., Planke, S., 2012. Rapid magma emplacement in the Karoo Large Igneous Province. Earth and Planetary Science Letters 325-326, 1-9.

Tegner, C., Duncan, R.A., Bernstein, S., Brooks, C.K., Bird, D.K., Storey, M., 1998. ${ }^{40} \mathrm{Ar}-{ }^{39} \mathrm{Ar}$ geochronology of Tertiary mafic intrusions along the East Greenland rifted margin: Relation to flood basalts and the Iceland hotspot track. Earth and Planetary Science Letters 156, 75-88.

Telford, W.M., Geldart, L.P., Sheriff, R.E., 1990. Applied Geophysics, 2nd ed. Cambridge University Press, Cambridge.

von Frese, R.R.B., Hinze, W.J., Braile, L.W., Luca, A.J., 1981. Spherical earth gravity and magnetic anomaly modeling by Gauss- Legendre quadrature integration. J. Geophys 49, 234-242.

Vuori, S., Luttinen, A.V., 2003. The Jurassic gabbroic intrusions of Utpostane and Muren: insights into Karoo-related plutonism in Dronning Maud Land, Antarctica. Antarctic Science 15, 283-301.

Watts, A.B., Stewart, J., 1998. Gravity anomalies and segmentation of the continental margin offshore Gabon, West Africa. Earth and Planetary Science Letters 156, 239-252. 
Wei, M., Schwarz, K.P., 1998. Flight test results from a strapdown airborne gravity system. Journal of Geodesy 72, 323-332.

White, R.A., McKenzie, D.P., 1989. Magmatism at rift zones: The generation of volcanic continental margins and flood basalts. Journal of Geophysical Research 94, 7685-7729.

Zhang, X., Luttinen, A.V., Elliot, D.H., Larsson, K., Foland, K.A., 2003. Early stages of Gondwana breakup: The 40Ar/39Ar geochronology of Jurassic basaltic rocks from western Dronning Maud Land,Antarctica, and implications for the timing of magmatic and hydrothermal events. Journal of Geophysical Research 108, doi:10.1029/2001JB001070. 


\section{Figures}

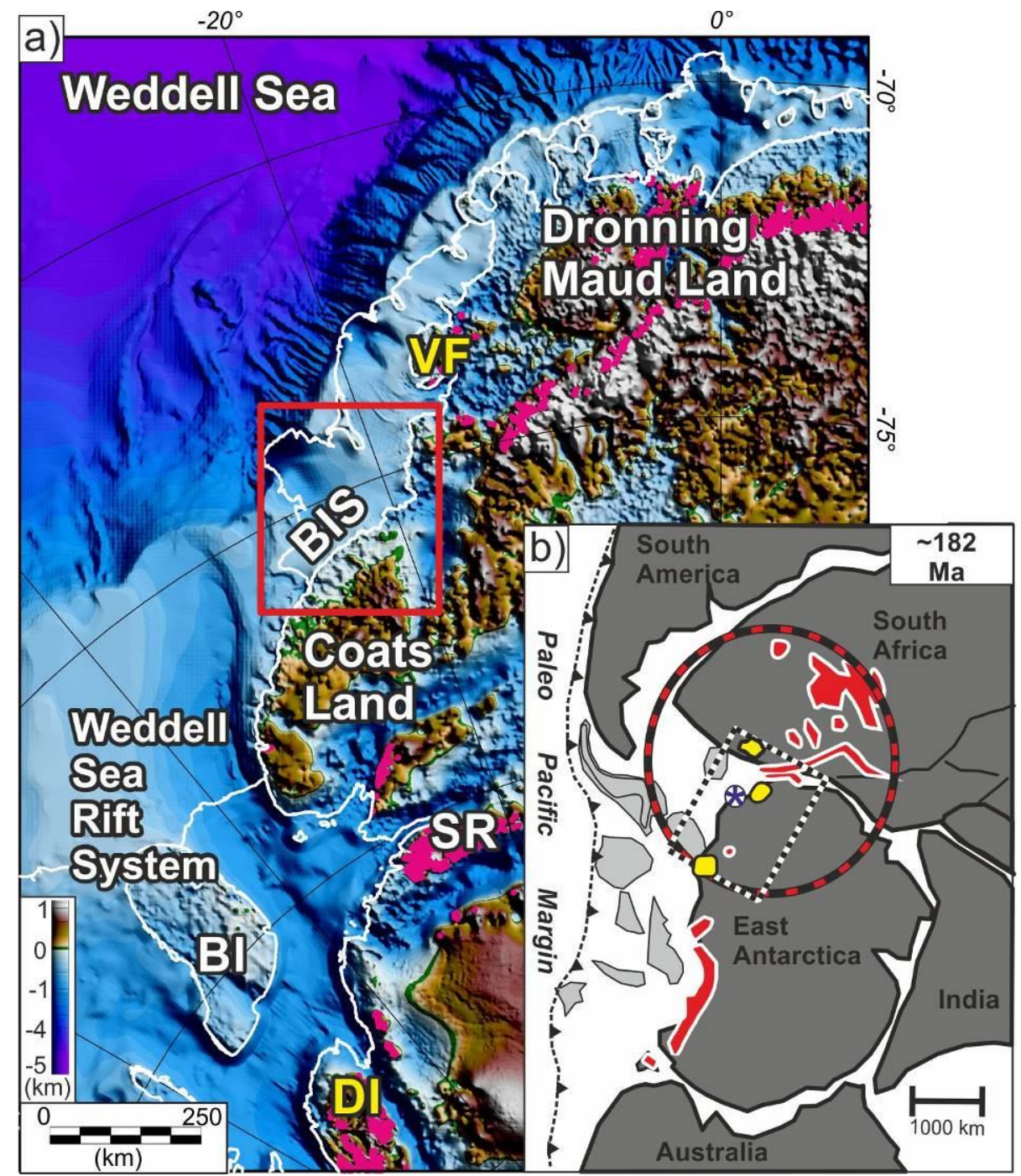

Fig. 1. Geographic and tectonic setting. a) Bathymetry and onshore sub-ice topography from BEDMAP2 (Fretwell et al., 2013). Red box over the Brunt Ice Shelf (BIS) locates Fig. 2. White lines show coast and ice shelf margins. Pink lines locate rock outcrops. Yellow letters mark gabbroic layered intrusions (Dufek Intrusion (DI) and in the Vestfjella area (VF)). SR and BI mark the Shackleton Range and Berkner Island respectively. b) Tectonic reconstruction of Gondwana (Dalziel et al., 2013; Jordan et al., 2017). Red areas mark Karoo-Ferrar magmas. Yellow areas locate exposed large gabbroic intrusions. Circle marks inferred plume head (White and McKenzie, 1989). Black and white dotted box locates (a). Blue star locates study area. Light and dark grey areas mark microcontinental fragments and continental blocks respectively. 


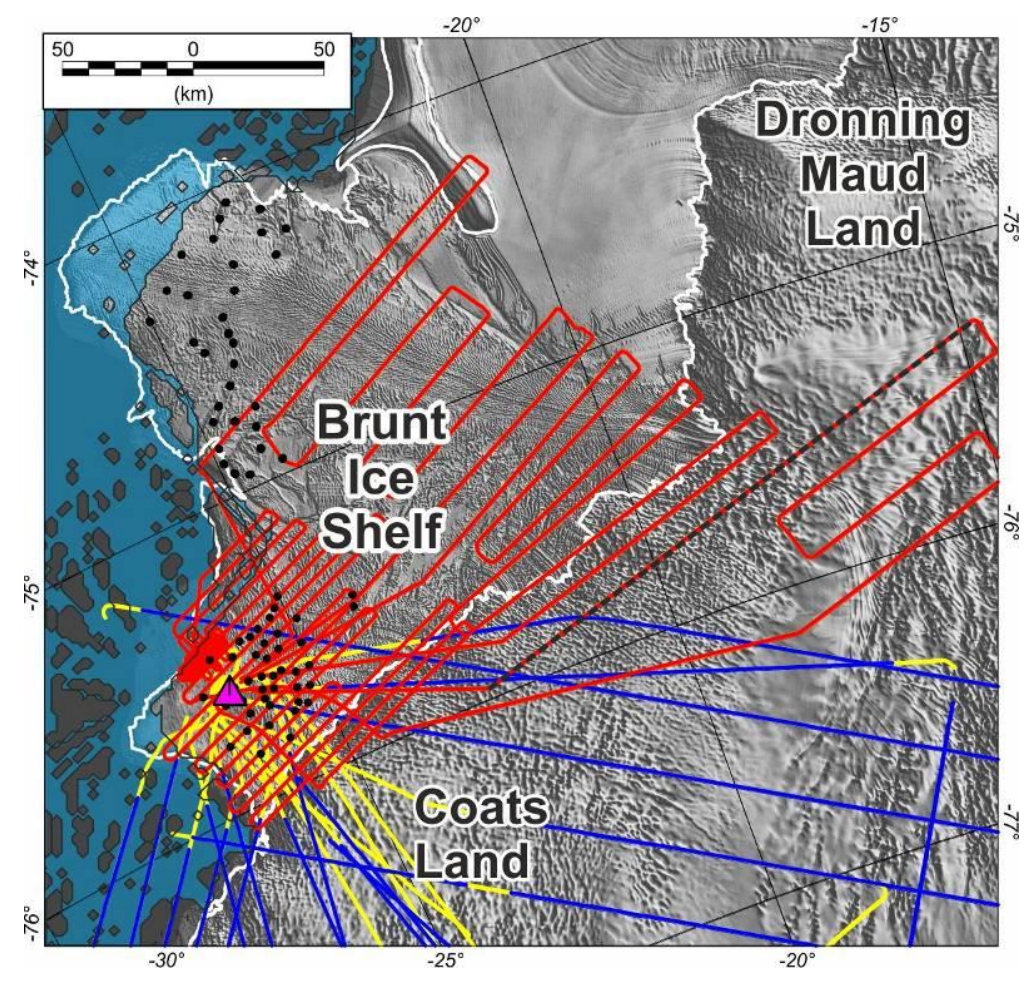

Fig. 2. Geophysical data coverage overlaid on MOA satellite image. Red lines mark strapdown gravity and aeromagnetic data from the 2017 survey flights. Blue lines mark gravity and magnetic data from ICEGRAV 2013 survey. Yellow lines locate areas with just magnetic data from the ICEGRAV 2013 survey. Pink triangle marks Halley Research Station. White line marks coast and edge of floating ice shelf. Black dashed line marks 2017 strapdown gravity profile chosen for spectral analysis (Fig. 3b). Black dots mark seismic determinations of sub-ice shelf bathymetry. Blue shading marks location of ship-borne swath bathymetric data. Note swath data beneath ice shelf was collected during times of past ice-shelf retreat. 

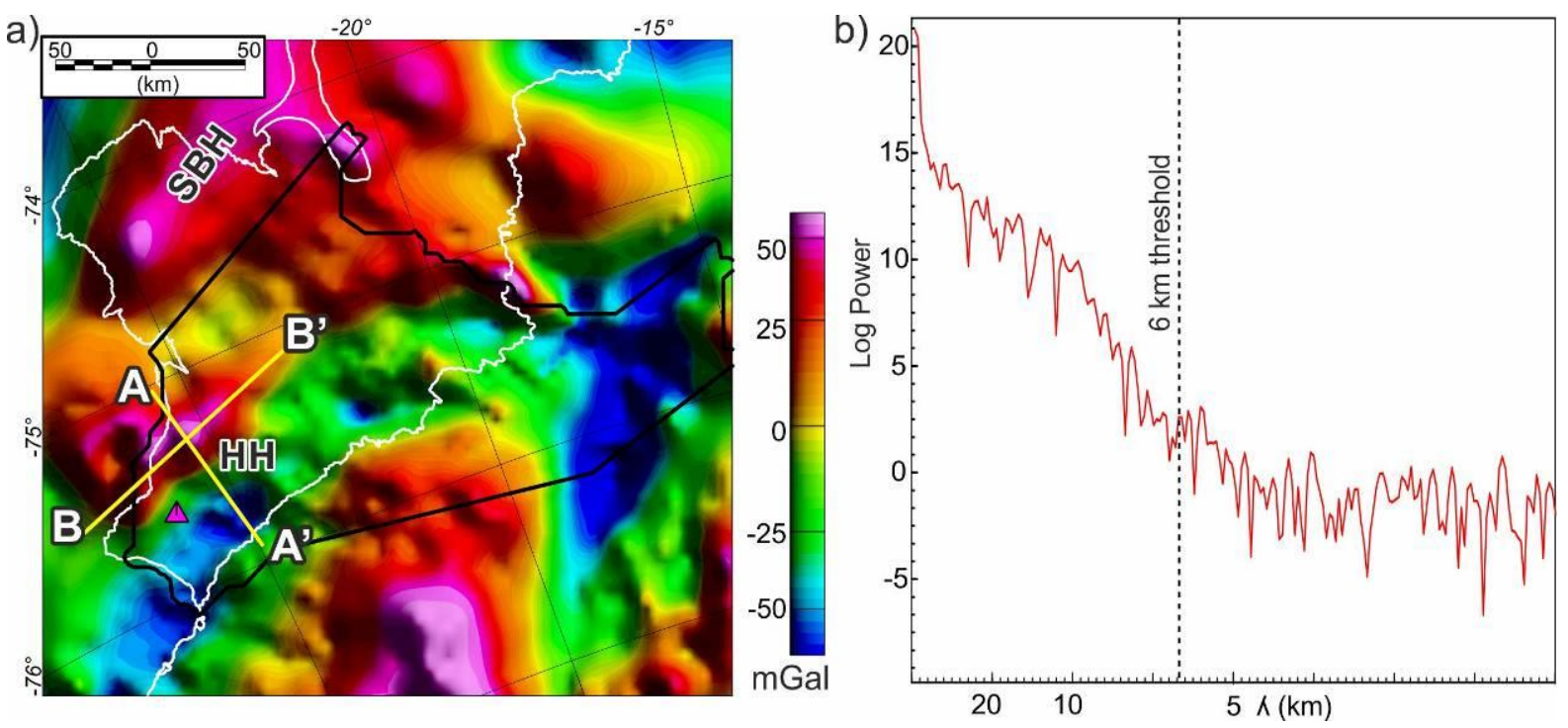

Fig. 3. Aerogravity data. a) Intergrated regional free air gravity anomaly. Black outline marks edge of 2017 high quality strapdown gravity data. Yellow lines locate modelled profiles (Fig. 7). HH = Halley High. SBH = Shelf Break High. b) Power spectrum of strapdown gravity flight line (Fig. 2) showing signal clearly above the noise floor by $6 \mathrm{~km}$ wavelength threshold. 

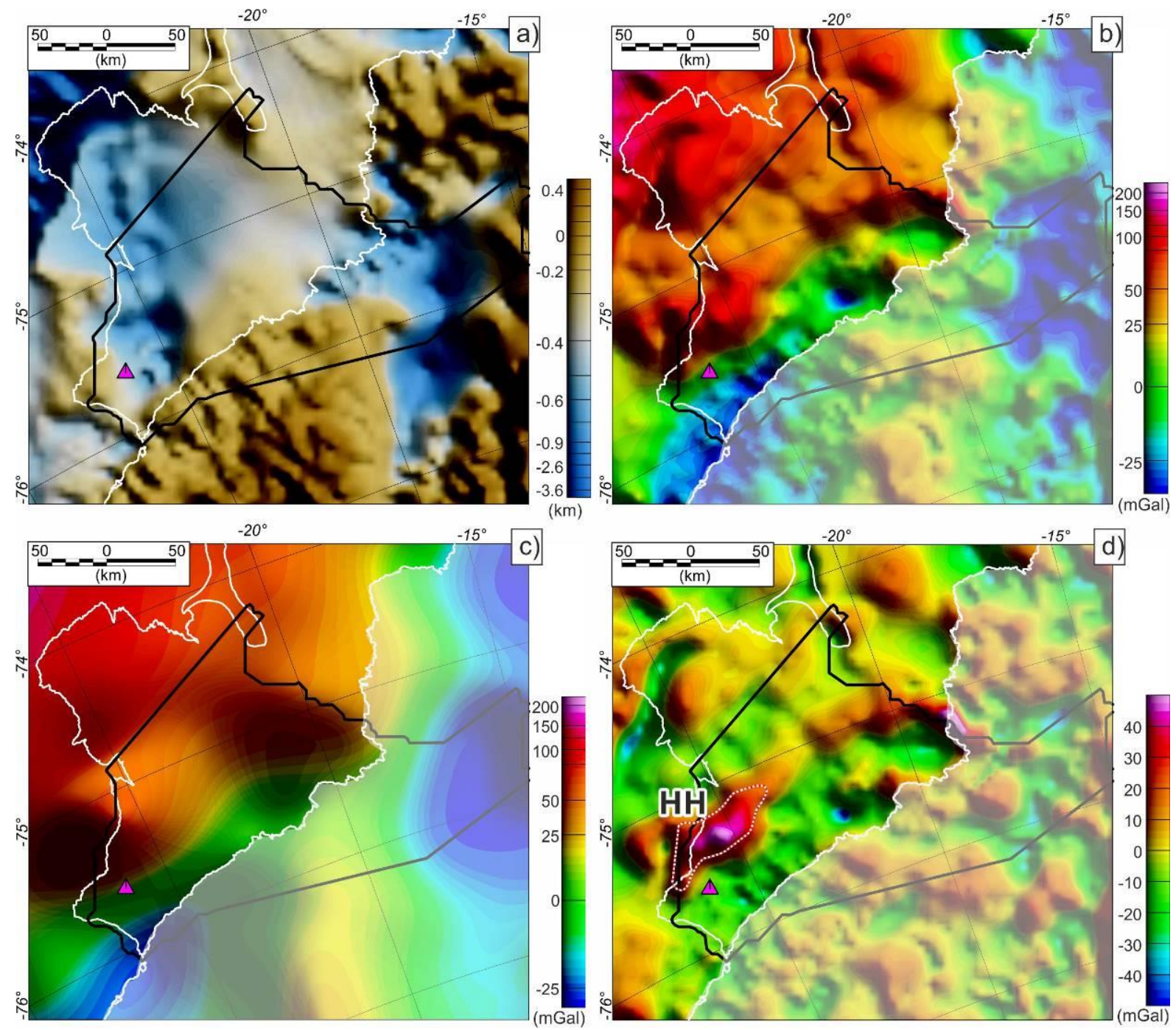

Fig. 4. Bathymetry and derived gravity anomalies. a) Bathymetry across the Brunt Ice Shelf, see Fig. 2 for data location. b) Bouguer gravity anomaly. Note onshore areas are masked as the gravity efect of topography above $450 \mathrm{~m}$ has not been acounted for. c) Long wavelength gravity residual reflecting changing crustal thickness from the East Antarctic continent to the Weddell Sea ocean. d) Residual gravity anomalies due to shallow geological features and remaining uncertainties in bathymetry. Note $\sim 50 \mathrm{mGal}$ Halley High $(\mathrm{HH}) \sim 30 \mathrm{~km}$ north of Halley Research Station. Red/white dashed line marks $+20 \mathrm{mGal}$ residual gravity contour around $\mathrm{HH}$ shown in subsequent figures. 


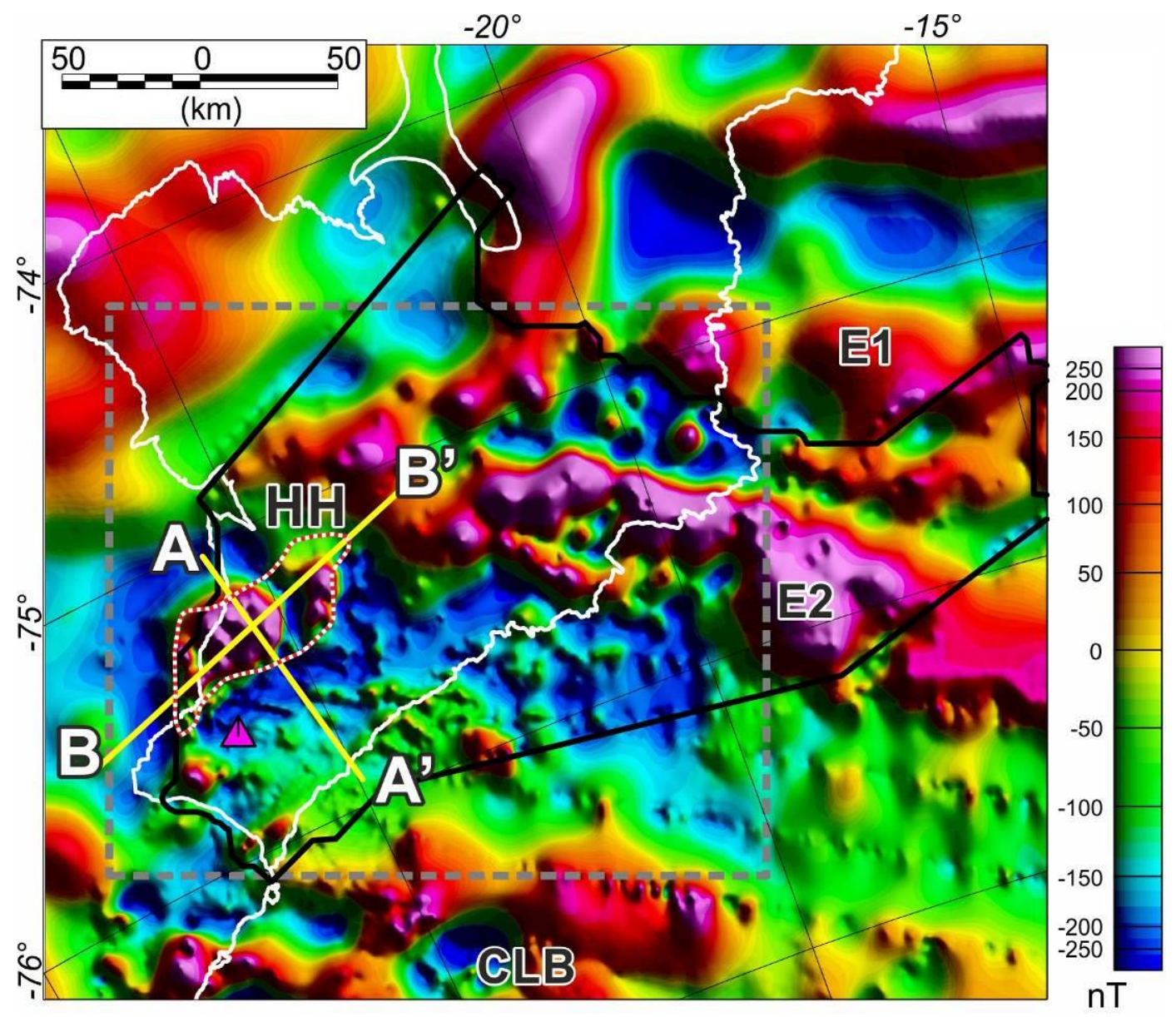

Fig. 5. Reduced to the pole (RTP) aeromagnetic data compilation across the Brunt Ice Shelf. Black line outlines highest resolution 2017 survey data. Grey dashed box locates Fig. 6. Yellow lines mark modelled profiles (Fig. 7). Anomalies E1 and E2 identify regional anomalies noted by previous authors (Mieth and Jokat, 2014). CLB marks the Coats Land Block, a previously inferred cratonic fragment (Studinger and Miller, 1999). Note positive magnetic anomalies within the outline of the Halley High gravity anomaly (red dashed line) have amplitudes of up to $1000 \mathrm{nT}$. 

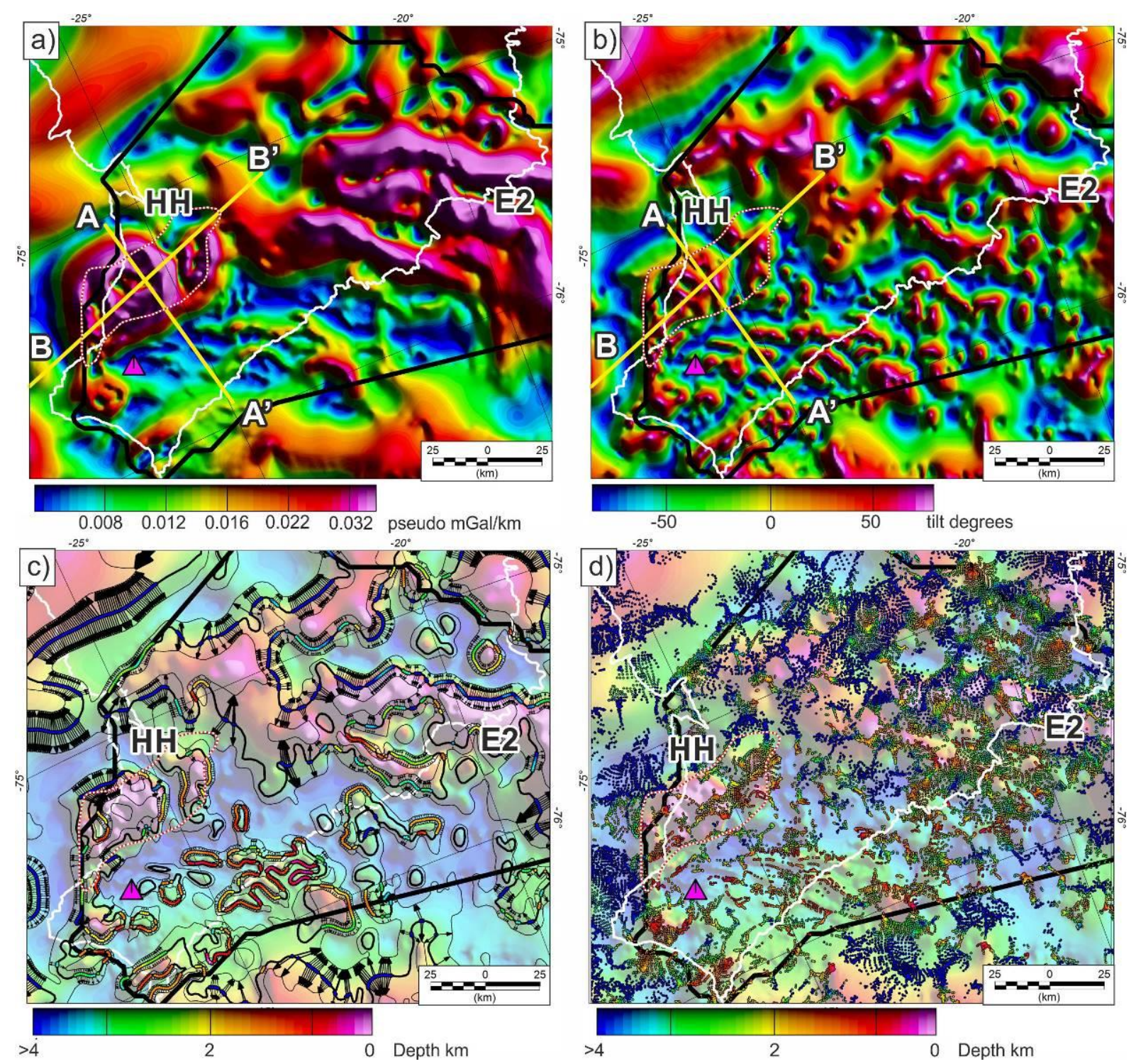

Fig. 6. Digital enhancement and depth to source calculation from aeromagnetic data. a)

Maximum horizontal gradient of pseudo-gravity. Peaks locate anomaly source margins. b) Tilt angle.

c) Tilt depth estimates passing the imposed quality threshold (coloured circles). Inferred source

margins indicated by $0^{\circ}$ tilt contour (thick black contour). $\pm 45^{\circ}$ tilt angle contours (thin black lines).

Arrows indicate direction from zero contour to closest $\pm 45^{\circ}$ contours for robust depth solutions.

Background image is RTP magnetic data (Fig. 5). d) 3D Euler depth solutions. Note clusters of shallow solutions along margins of anomalies. Broad 'spray' patterns of solutions $>4 \mathrm{~km}$ depth occur in areas with lower resolution regional data. 

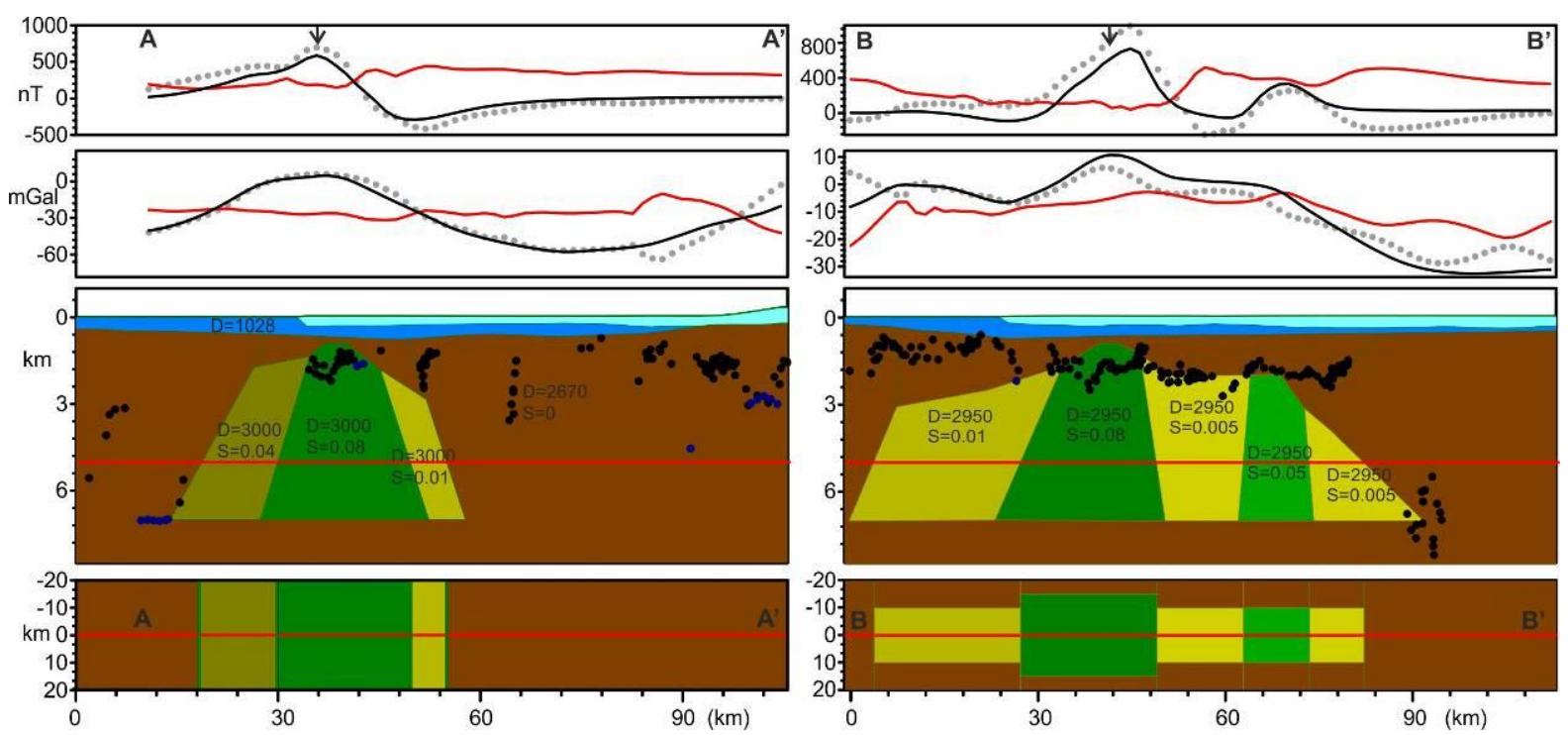

Fig. 7. Potential field models across the Halley High anomalies, location on previous figures.

a) N-S profile A-A'. b) W-E profile, B-B'. Top panel modelled (black line) and observed (grey dots) magnetic anomalies, and residual field (red line). Small black arrows locate profile intersections. Second panel shows modelled (black line) and observed (grey dots) upper crustal gravity anomalies, and residual field (red line). Third panel shows vertical section of model. Pale and dark blue blocks reflect ice and water respectively. Brown shows rock with a modelled background density of 2670 $\mathrm{kgm}^{-3}$ and zero susceptibility. Text shows block density (D) in $\mathrm{kgm}^{-3}$ and magnetic susceptibility (S) in SI units. Green to yellow blocks are the modelled sources, differing shades reflect changing susceptibility. Black dots mark 3D extended Euler depth to source solutions. Blue dots mark tilt depth solutions. Horizontal red line locates 2D section view. Lower panel shows 2D section view of model at $5 \mathrm{~km}$ depth. Note model $\mathrm{A}-\mathrm{A}^{\prime}$ is infinite across strike, but in model B-B' the source bodies are modelled as extending $10-15 \mathrm{~km}$ from the profile. 

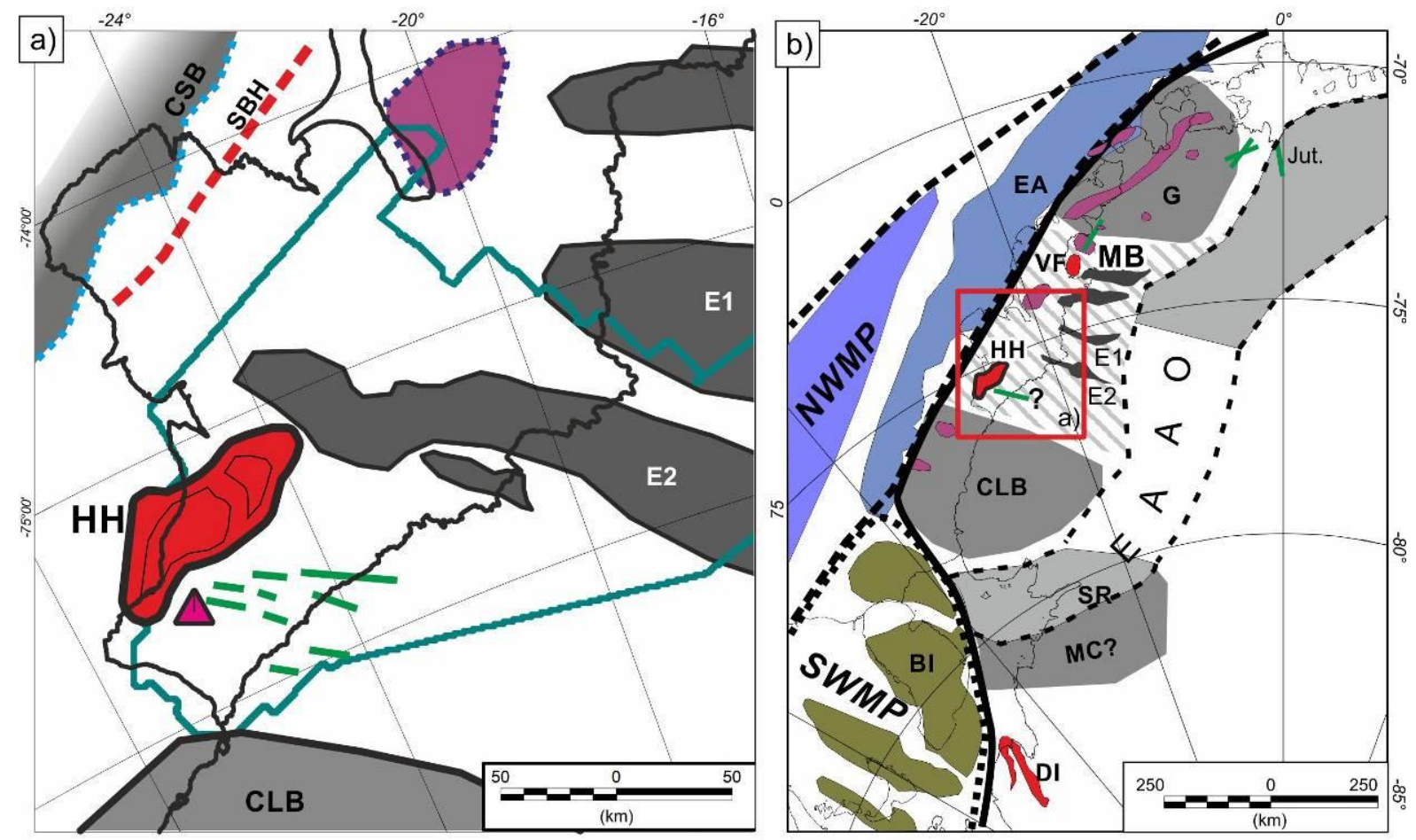

Fig. 8 Geophysical interpretation and discussion. a) Detailed interpretation of 2017 survey area (blue outline). The Halley High $(\mathrm{HH})$ is interpreted as a large Jurassic mafic intrusion (red). Anomalies E1 and E2 are Grenville age basement structures. Lineations south of the Halley High (green) may be basement structures or dykes originating from the Halley High intrusion. Purple region is a previously inferred Jurassic mafic intrusion (Golynsky and Aleshkova, 1997). Note continental shelf break (CSB) and parallel shelf break gravity high ( $\mathrm{SBH}$ ) reflect the Jurassic rifted margin and parallel the trend of the Halley High. South of the survey area is the Coats Land Block (CLB). b) Regional setting. Red bodies reflect gabbros identified from our detailed geophysical analysis (HH), or outcrop; Vestfjella (VF) and Dufek Intrusion (DI). Purple bodies mark other inferred Jurassic mafic intrusions within the East Antarctic continent (Golynsky and Aleshkova, 1997). Green lines mark dominant trends of mafic dikes. The Northern and Southern Weddell Magnetic Provinces (NWMP - blue and SWMP - dark green) reflect regions of extended continental crust dominated by continental breakup and back-arc extension respectively (Jordan et al., 2017). The Berkner Island anomaly (BI) and other structures within the SWMP are modelled as intrusions. The linear Explora Anomaly (EA) is interpreted to be a seaward dipping reflector sequence (Kristoffersen et al., 2014). 
East Antarctica provinces in dark grey mark cratonic blocks including the Grunehogna Craton (G), $\mathrm{CLB}$, and northern edge of the Mawson Continent (MC). The grey striped region marks the interpreted broad 1Ga Maud Belt (MB) with internal anomalies in black (Mieth and Jokat, 2014). The 500 Ma East African Antarctic Orogen (EAAO) may link the Shackleton Range (SR) and the Jutulstraumen (Jut.) area (Jacobs and Thomas, 2004). 